\title{
Evidence for potential underestimation of clinical folate deficiency in resource-limited countries using blood tests
}

\author{
Aśok C.Antony \\ From the Division of Hematology-Oncology, Department of Medicine, Indiana University \\ School of Medicine, and the Roudebush Veterans Affairs Medical Center, Indianapolis, Indiana \\ 46202
}

Address correspondence to: Prof. Aśok C. Antony, MD, MACP, 980 West Walnut Street, R3-

C321B, Walther Hall, Indianapolis, Indiana 46202, USA.

Key Words: Serum folate, vitamin- $\mathrm{B}_{12}$, malaria, pregnancy, pediatrics

Running Title: Underdiagnosis of folate deficiency by blood tests

This is the author's manuscript of the article published in final edited form as:

Antony, A. C. (2017). Evidence for potential underestimation of clinical folate deficiency in resource-limited countries using blood tests. Nutrition Reviews, 75(8), 600-615. https://doi.org/10.1093/nutrit/nux032 


\section{ABSTRACT}

Although a low serum folate concentration is a useful biomarker of pure folate deficiency, the coexistence of either vitamin- $B_{12}$ deficiency and/or hemolysis predictably raises serum folates. Therefore in resource-limited settings where dietary folate deficiency can coexist with vitamin- $B_{12}$ deficiency and/or malaria, the serum folate concentration can be normalto-high, leading to serious underestimation of tissue-folate status. This review traces the genesis of an inappropriate overreliance on results of the serum folate concentration to rule out folate deficiency in such vulnerable populations of women and children; of significance, without due consideration of a chronically inadequate dietary folate intake, these populations have likely been wrongly judged to have an adequate folate status in influential studies. Through repetition, this error has led to a dangerous entry into the contemporary medical literature that folate deficiency is rare in these populations! As a consequence of this apologue, many millions of such women and children with mild-to-moderate tissue folate deficiency may have been deprived of folate replacement. This review uses historical documents to challenge earlier conclusions and re-emphasizes the need for contextual integration of clinical information in resource-limited settings.

\section{Introduction}

Food-fortification with folic acid has markedly reduced the incidence of folate deficiency and neural-tube defects wherever flour is centrally processed and equitably distributed to the general population. ${ }^{1,2}$ However, despite such initiatives in several developed and developing countries, for a variety of reasons ${ }^{2,3}$ up to $90 \%$ of the world's women who primarily reside in resourcelimited countries are apparently still not receiving sufficient dietary folate. ${ }^{4}$ Therefore if these women continue to consume insufficient folate during pregnancy, their progeny will begin life 
with a low store of folates, which tends to propagate the problem of intergenerational folate deficiency ad infinitum. Yet, the contemporary literature is rife with reports from resourcelimited countries that folate deficiency is less common than previously thought, and is rare, even among vulnerable populations that chronically consume a low-folate diet. What are the sources behind this bold conclusion?

There are well known limitations in use of the serum folate concentration as a biomarker for diagnosis of folate deficiency among subjects with vitamin- $\mathrm{B}_{12}$ deficiency and/or hemolytic diseases like malaria. ${ }^{1,5,6}$ Thus, an intracellular metabolic block in folate utilization during vitamin- $\mathrm{B}_{12}$ deficiency results in raised serum folates which return to baseline only after vitamin$\mathrm{B}_{12}$ replacement; therefore the finding of a normal serum folate level in such patients with untreated vitamin- $\mathrm{B}_{12}$ deficiency can underestimate the extent of tissue folate deficiency. Similarly, hemolysis of red cells that accompanies malaria also releases the extant 30 -fold higher erythrocyte folate concentration into plasma, thereby raising the serum folate level; this too can mask true folate deficiency.

A central tenet of this review is that without sufficient consideration of the limitations of the serum folate concentration in the presence of coexistent vitamin- $\mathrm{B}_{12}$ deficiency and/or malaria in resource-limited countries, several investigators have categorically interpreted the results of a normal serum folate level as signifying a normal folate status. As a consequence, they have erroneously eliminated folate deficiency from consideration particularly among vulnerable populations of women and children who reside in these regions where a chronically poor folate intake is the norm. This potentially serious error from a few influential publications has led to a 'snowball effect' where continued repetition [of this error] by these and other investigators (from many disciplines of medicine) has led to the widespread conclusion that folate deficiency is rare in those very populations that urgently need folate supplementation. 
Since it is so important not to miss the diagnosis of folate deficiency particularly among women and children ${ }^{1,6,7}$-and analysis of the literature will show this has likely been the casethe rationale for this review is to identify the genesis of how this error entered the literature, and then point to evidence from alternate sources that provides a sufficiently robust challenge to reverse this misconception.

The approach of this narrative review will be: $(i)$ To provide a historical perspective on data from seminal papers which identified how associated conditions like vitamin- $B_{12}$ deficiency and/or hemolysis predictably gave abnormal test results for serum folates [or erythrocyte folates]; (ii) to identify those high-profile papers from resource-limited countries that have likely misinterpreted the results of normal serum folate levels in the presence of these confounding variables (vitamin- $\mathrm{B}_{12}$ deficiency and/or malaria), leading to an underestimation of folate deficiency; and (iii) to note how amplification of this error, through repetitive citation, has become embedded as 'a fact' in the current medical literature. (iv) Where there is a paucity of information in the literature, an attempt has been made to frame the key questions that need to be resolved. Finally, $(v)$ where interpretation of non-invasive and invasive tests remains problematic or ambiguous, the imperative for prophylaxis is discussed within the context of the geographic, socio-economic, and dietary history of vulnerable populations.

Search strategy and literature selection criteria. Data for this review was obtained by searching PubMed for all available articles published in English (up to August 2015), which contained any two of the following search terms "folate deficiency", "vitamin-B ${ }_{12}$ deficiency", "pregnancy", "malaria" or "hemolysis". The choice of articles that were subsequently reviewed in more detail was then based on four additional [inclusion] criteria: First, whether these articles were among the high-profile papers that originated the premise that folate deficiency was rare in resource-limited countries based primarily on the test results of serum folate levels. Second, the 
studies were conducted in populations where there was no consumption of folate-fortified food or multivitamins. Third, whether there were source documents from other contemporary studies or other disciplines that provided insight into the prevailing nutritional or social context of these populations, and if such documents pointed to a high likelihood of coexisting nutritional vitamin$\mathrm{B}_{12}$ deficiency and/or malaria. Fourth, if such revelations allowed for a sufficiently strong challenge to seriously question the veracity of the earlier conclusions.

Shortcomings in the diagnosis of tissue vitamin deficiency when blood tests for vitamin-B $\mathbf{B}_{12}$ and folate are solely used - the importance of clinical details. In several papers analyzed in this review, studies on the vitamin- $B_{12}$ and folate status of subjects in resource-limited countries were conducted in the absence of clinical details. Such studies are incomplete because they fail to provide information on dietary intake or other clinical symptoms and/or signs, and on whether there is associated megaloblastic anemia (reflective of tissue deficiency of either vitamin- $\mathrm{B}_{12}$ or folate) and/or neuropsychiatric abnormalities (reflective of tissue deficiency of vitamin- $\mathrm{B}_{12}$ ). Such information is important because it is well established that even when subjects with vitamin- $\mathrm{B}_{12}$ deficiency are ambulatory, megaloblastic anemia can be present without major symptoms. For example, it is not uncommon for subjects in India and African countries to be fully ambulatory with megaloblastic anemia and hemoglobin levels of 9-10 grams/deciliter (or lower) with minimal to no symptoms; this is because the body has compensated over the long duration it takes to develop vitamin- $B_{12}$ deficiency. ${ }^{1,6,8}$ Such symptoms can often be only elicited by leading questions in conjunction with a comprehensive physical examination ${ }^{1,9}$. Moreover, among ambulatory subjects with biomarkers that suggest vitamin- $\mathrm{B}_{12}$ deficiency, it may even require sophisticated neurological testing to reveal evidence for subtle abnormalities that reflect tissue deficiency of vitamin- $\mathrm{B}_{12} \cdot{ }^{10-12}$ It should be noted that in resource-limited countries, apart from a primary dietary deficiency of folates, when vitamin- $\mathrm{B}_{12}$ deficiency is prolonged, 
megaloblastosis of the intestinal cells can also predispose to a secondary malabsorption of [the already meager intake of] dietary folate; this can lead to folate deficiency developing late in the course of vitamin- $\mathrm{B}_{12}$ deficiency. ${ }^{8,13}$ Therefore in the absence of clinical data, the extent of tissue deficiency of vitamin $\mathrm{B}_{12}$ deficiency and/or folate cannot always be definitively ascertained merely from the serum level. ${ }^{1,6,8}$

Limitation of the serum folate biomarker in the setting of vitamin- $B_{12}$ deficiency $=a$ historical perspective. In the early days, microbiological assays using bacteria that thrived on folate for their growth were used to measure the serum and erythrocyte folate concentration. Using such assays, hematologists in North America and the United Kingdom established that patients with anemia due to folate deficiency had low serum and erythrocyte folate concentrations (Table 1); this made it a useful standardized and objective measure in the clinical assessment of folate status in patients with anemia. However, when these investigators searched for other clinical conditions that could consistently raise the serum folate concentration, they

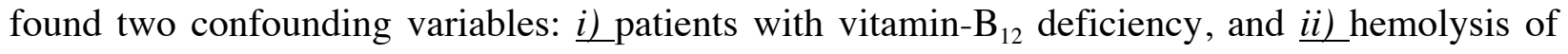
red blood cells. Thus, as early as 1962, among 100-consecutive patients with pernicious anemia, megaloblastic anemia, and a low serum vitamin- $\mathrm{B}_{12}$ less than $100-\mathrm{pg} / \mathrm{ml}$, Herbert and Zalusky identified that "one-third with vitamin- $\mathrm{B}_{12}$ deficiency had falsely high serum folate levels". ${ }^{14}$ These pioneers were remarkably prescient in their suggestion that in the presence of mild-tomoderate tissue folate deficiency, the serum folate would be in the normal range in the presence of vitamin- $\mathrm{B}_{12}$ deficiency. Likewise Waters and Mollin ${ }^{15}$ observed in 1963: "The highest serum folate (L. casei) levels were found in patients with the lowest serum vitamin- $B_{12}$ levels. As the serum vitamin- $B_{12}$ level increased there was a progressive fall in the serum folate level..." In 11patients, they observed "[a] rapid fall in the mean serum folate level to approximately a third (34\%) of the pre-injection mean during the first 24 hours after an injection of 1000- $\mu$ g of 
vitamin- $\mathrm{B}_{12}{ }^{\prime \prime} \cdot{ }^{15}$ Thus, if the serum folate concentration was at a low-normal range at baseline (prior to vitamin- $B_{12}$ injection), the subsequent reduction in serum folate levels after vitamin- $\mathrm{B}_{12}$ could easily have dropped into a folate-deficient range.

Indeed, a year later, Cooper and Lowenstein ${ }^{16}$ documented a predictable movement of previously high serum folate values towards lower [baseline] levels in all 10-patients with pernicious anemia following correction of vitamin- $B_{12}$ deficiency. Similarly, after vitamin- $\mathrm{B}_{12}$ replacement of 15-Indian children (aged 6-months to 12-years) who were suffering from nutritional anemia due to vitamin- $B_{12}$ deficiency, ${ }^{17}$ the serum folate concentration dropped in 6 of 15-patients $(40 \%)$ from previously normal values (mean of $17 \cdot 6-\mathrm{ng} / \mathrm{ml}$ ) to a deficient level with a mean of $4 \cdot 8-\mathrm{ng} / \mathrm{ml}$ (their cut-off values for folate deficiency were less than $6-\mathrm{ng} / \mathrm{ml})^{18}$; this suggested that this cohort likely had associated masked folate deficiency. In addition, among 5 of 15-patients, serum folates remained persistently low even after vitamin- $\mathrm{B}_{12}$, consistent with associated overt severe folate deficiency. Thus, whereas 11 of 15 -patients (73\%) of these children actually had a combined vitamin- $\mathrm{B}_{12}$ plus folate deficiency, a full $40 \%$ of patients with folate deficiency would have been missed if only a single serum folate test value was available. [This is an important point because we will shortly see how other clinical investigators in resource-limited countries have erroneously made the diagnosis of 'pure' vitamin- $\mathrm{B}_{12}$ deficiency from only a single blood test result (that revealed a low serum vitamin- $\mathrm{B}_{12}$ but normal folate levels), which has likely missed significant numbers of patients with associated folate deficiency (Table 1)].

Nixon and Bertino ${ }^{19}$ then determined that accumulation of serum folate in patients with vitamin- $B_{12}$ deficiency (pernicious anemia) - and its fall after treatment with vitamin- $B_{12}$ - involved decreased clearance, reduced cellular metabolism, and increased renal excretion of 5-methyltetrahydrofolate. These results were consistent with the "methyl-folate trap" hypothesis - reflecting 
poor utilization of folate during vitamin- $\mathrm{B}_{12}$ deficiency to explain why hematological manifestations of vitamin-B $B_{12}$ deficiency resembled folate deficiency (Figure 1). Parenthetically, Nixon and Bertino ${ }^{19}$ also predicted that administering folate to vitamin- $\mathrm{B}_{12}$-deficient subjects would lead to "a several-fold elevation of the total serum folate concentration..." Indeed, fifteen years later, among a cohort with vitamin- $\mathrm{B}_{12}$ deficiency, Stabler et $a l^{20}$ documented that those consuming folate-rich multivitamins had the highest recorded serum folate values.

Is there a threshold whereby there is a failure in maintaining the inverse relationship between low serum vitamin- $\mathrm{B}_{12}$ and higher serum folate? Thus far, we have considered the close relationship between a low serum vitamin- $\mathrm{B}_{12}$ level and an inverse rise in serum folate level among subjects with clinical findings of anemia attributable to vitamin- $\mathrm{B}_{12}$ deficiency. Whether such an inverse relationship holds throughout the spectrum of severe-, moderate-, and mild- vitamin- $\mathrm{B}_{12}$ deficiency, or there is a particular threshold level (such as in mild serum vitamin- $\mathrm{B}_{12}$ deficiency when megaloblastic anemia has not yet manifested clinically) where this inter-relationship is not sustained, is not known. However, it is well established that the metabolic effects of vitamin- $B_{12}$ deficiency that lead to a functional (and later real) intracellular functional folate deficiency ${ }^{21}$ always precede the morphological manifestations of megaloblastic anemia. ${ }^{1,6,8}$ Therefore it would appear that this inverse relationship in serum vitamin- $\mathrm{B}_{12}$ and folate levels would hold firm even in mildto-moderate vitamin- $\mathrm{B}_{12}$ deficiency, and occur even before clinical findings of nutritional anemia were manifest. This is consistent with the earlier clinical observations ${ }^{15}$ and the dynamic changes in serum folate upon replenishment of vitamin- $\mathrm{B}_{12} \cdot{ }^{17}$ This is an area for future investigation.

Red blood cell (RBC) folates as a measure of folate stores - a historical perspective. Unlike the serum folate, which is entirely 5-methyl-tetrahydrofolate, RBC folates consist of a heterogeneous mixture of different coenzyme forms with varying polyglutamate chain lengths. Clinical measurement of RBC folates took on importance when tissue folate deficiency was clinically 
correlated with a decrease in RBC folate (less than $150 \mathrm{ng} / \mathrm{ml}$ ) by a microbiological assay in the 60 's ${ }^{22}$. Thus finding a decreased serum and RBC folates with megaloblastic anemia was consistent with the diagnosis of folate deficiency. Although this seemed like the ideal combination to diagnose folate deficiency, RBC folate tests had major limitations in sensitivity and specificity ${ }^{8,23,24}$, and were notoriously unreliable in alcoholics and in pregnancy; thus, it was normal/borderline in approximately $30 \%$ of alcoholics ${ }^{23}$ and $60 \%$ of pregnant patients ${ }^{25}$ with clinically significant folatedeficient megaloblastic anemia. Furthermore, a reduction of $\mathrm{RBC}$ folate also occurs in approximately $60 \%$ with vitamin- $\mathrm{B}_{12}$ deficiency, further limiting its diagnostic utility. ${ }^{8}$

There is a further twist to this issue: the original microbiological assays for RBC folates have been replaced by radioassays currently used for measurement of serum folate levels. Apart from a lack of clinical validation of the use of radioassays for measuring RBC folates, these radioassays have had a long history of being unreliable with respect to lack of precision and accuracy, generally leading to a lack of confidence in the results. ${ }^{26}$ In addition, a quality assurance study from Australasia involving 134 laboratories identified nine (operator controllable) factors which could also lead to poor RBC folate results. ${ }^{27}$ And later analysis of its clinical value led to the conclusion that the $\mathrm{RBC}$ folate test added little useful information to that provided by serum folate levels. ${ }^{28}$ Together, these clinically relevant issues have considerably dampened enthusiasm for use of RBC folate tests, leading several experts to entirely avoid their use pending a resolution of problems related to reagent batch quality control, quality assurance, and equally important, provision of data on clinical validation by the various manufacturers of these kits.

Therefore because of intrinsic problems of poor validation and unreliability, commercial $\mathrm{RBC}$ folate assays are not routinely used in the clinical diagnosis of folate deficiency ${ }^{1,29}$; so now, serum folates are primarily used for population-wide assessment of folate status in resource-rich 
settings $^{30-32}$ as well as for routine clinical diagnosis of folate deficiency. ${ }^{1,6}$ However, as noted above, the serum folate test has limitations in resource-limited populations where consumption of both vitamin- $\mathrm{B}_{12}$ and folate are poor.

Clinical use of sensitive metabolite levels to diagnose vitamin-B $B_{12}$ and/or folate deficiency = a historical perspective. By the late 1980's, the combination of serum homocysteine and serum methylmalonic acid tests were introduced clinically as far more sensitive diagnostic markers of vitamin- $B_{12}$ deficiency than measurement of serum vitamin- $B_{12}$ concentrations. ${ }^{20,33}$ However, it should be noted that the serum homocysteine is also increased in folate deficiency ${ }^{6,20,33}$ (Table 2). Therefore although high serum homocysteine and methylmalonic acid levels can reflect underlying vitamin- $\mathrm{B}_{12}$ deficiency, a combined vitamin- $\mathrm{B}_{12}$ plus folate deficiency cannot possibly be ruled out by a single set of tests ${ }^{6,20,33}$; see Table 1 and Table 2 . Indeed, the only way to prove that a patient has pure vitamin- $\mathrm{B}_{12}$ deficiency involves a laborious, costly, and impractical approach of serial reassessment of both the serum homocysteine and methylmalonic acid values after vitamin- $B_{12}$ replacement. Thus, with pure vitamin- $B_{12}$ deficiency, both serum homocysteine and methylmalonic acid should drop completely into the normal range; however, if folate deficiency was also present, although the serum methylmalonic acid concentration would normalize, the serum homocysteine would not completely drop into the normal range. ${ }^{34}$ Needless to state, except for isolated exemplars ${ }^{35}$, such detailed studies using metabolites ${ }^{20,33}$ have not been reported among large cohorts of subjects from resource-limited settings. But by the same token, any study purporting to having diagnosed patients with 'pure' vitamin- $\mathrm{B}_{12}$ deficiency - (using evidence from a single blood test showing low serum vitamin- $\mathrm{B}_{12}$ and normal serum folate values, and/or combined elevated serum methylmalonic acid and serum homocysteine values) - cannot have unambiguously ruled out an associated folate deficiency, particularly in resource-limited settings where dietary folate intake is persistently inadequate. 
Yet, many high-profile studies have made precisely such claims, as discussed below.

\section{Masking of folate deficiency with coexistent vitamin- $B_{12}$ deficiency}

1. Non-pregnant adults in India. When Refsum et $a l^{36}$ evaluated an ambulatory population in Pune with a single set of blood tests (without dietary or clinical information), they reported that $47 \%$ had serum vitamin- $B_{12}$ values that were consistent with vitamin- $B_{12}$ deficiency (less than 150-pmol/L), but apparently less than $5 \%$ had evidence of folate deficiency based on serum folate levels (less than 5-nmol/L). In addition $77 \%$ had hyperhomocysteinemia (more than 15 $\mu \mathrm{mol} / \mathrm{L}$ ) and $73 \%$ had elevated serum methylmalonic acid (more than $0 \cdot 26-\mu \mathrm{mol} / \mathrm{L}$ ). On this basis, these investigators correctly concluded that vitamin- $\mathrm{B}_{12}$ deficiency was widespread among three-quarters of the population studied. However, their conclusion that folate deficiency was not a major problem is incorrect ${ }^{36}$ because only a single blood sample was assessed, and intentional studies designed to specifically unmask associated folate deficiency-by longitudinal measurement of serum folate values before and after vitamin- $B_{12}$ replacement ${ }^{16,17,34}$ - were not conducted. Because homocysteine is elevated in both vitamin- $\mathrm{B}_{12}$ and folate deficiency, these investigators did not unambiguously rule out an associated folate deficiency; this could have been shown out by first demonstrating a failure to drop the serum homocysteine into the normal range after vitamin- $\mathrm{B}_{12}$ therapy, and then confirming a further drop in serum homocysteine into the normal range only upon addition of folate replacement]. Therefore, Refsum et $a l^{36}$ have not unambiguously ruled out a combined vitamin- $\mathrm{B}_{12}$ plus folate deficiency. ${ }^{37}$ Because the average serum folate was $12 \cdot 2-\mathrm{nmol} / \mathrm{L}$ [or $5.38-\mathrm{ng} / \mathrm{ml}$ ] (i.e., in the low-normal range of the assay which had an upper limit of approximately $45-\mathrm{nmol} / \mathrm{L}$ ) - and based on the potential for masking of folate deficiency during vitamin- $\mathrm{B}_{12}$ deficiency ${ }^{15-19,22}$-it is quite possible that vitamin- $\mathrm{B}_{12^{-}}$ replenishment could have led to either a drop of serum folate concentrations below the lower limit of normal, or an incomplete drop of homocysteine into the normal range. Indeed, a 
subsequent study from this region provided precisely such evidence to support the possibility of an associated folate deficiency ${ }^{38}$ : Thus, in a small subgroup of non-pregnant women from Pune, following replacement with alternative days of $500-\mu \mathrm{g}$ oral methyl-vitamin-B ${ }_{12}$ over 6 weeks, ${ }^{38}$ these investigators observed: "Normalization of tHcy [total serum homocysteine] was obtained in only 4/11 women, while seven women continued to be hyperhomocysteinemic despite improvement of vitamin- $B_{12}$ status within 'normal' range and despite a normal folate status." However, the serum folate value of those women believed to have "a normal folate status" was actually in the borderline low-normal range, with a median value of 4.4-ng/ml at baseline (25\%, $75^{\text {th }}$ centile $=2.4-$ and $5.8-\mathrm{ng} / \mathrm{ml}$, respectively, with a cut-off value of less than $3.0-\mathrm{ng} / \mathrm{ml}$ signifying frank folate deficiency). ${ }^{38}$ Therefore women at the ' $25^{\text {th }}$ centile' clearly had laboratory evidence of folate deficiency, whereas many others had values in the low-normal range; and because they were not replenished with folate, their serum homocysteine likely failed to drop into the normal range, as would be predicted in a population with combined low vitamin- $\mathrm{B}_{12}$ and folate status. Equally revealing was the finding that "green leafy vegetables did not alter the serum folate or tHcys [total serum homocysteine]". ${ }^{38}$ This reflects the well-known low bioavailability of folate in such foods after cooking. ${ }^{1,39}$ The existence of nutritional folate deficiency among these women should not be surprising because this predominantly vegetarian and near-vegetarian ${ }^{7,37}$ population subsists on well-cooked lentils, beans, and vegetables and only small portions of dairy (yogurt/milk), occasional eggs and seasonal fruit; moreover fresh salad greens are not customarily consumed. Even the non-vegetarian population consumes a similar diet as vegetarians but with the inclusion of only small portions of curried meats - at most twice a week. ${ }^{7,37}$ Therefore, in analogy to the data from Saraya $e t$ al ${ }^{17}$ in Indian children, there were a number of adult women in the study by Yajnik et $a l^{38}$ who were already folate-deficient; this fact could prevent a rise from preexisting low levels (following vitamin- $\mathrm{B}_{12}$ replacement) into the 
normal folate range as had been previously observed in Indian children. ${ }^{17}$ While one cannot state with certainty-because intentional longitudinal replenishment studies have not been carried out-when taken together, these issues support the likelihood that the population studied in Pune $^{36}$ had many more patients with combined vitamin- $\mathrm{B}_{12}$ and folate deficiency ${ }^{37}$ than the publication originally suggested. Yet the repetitive misinterpretation of findings of a single normal serum folate level as ruling out folate deficiency in this population ${ }^{36}$ has evolved over the years into a much more definitive assertion - as exemplified in this abstract ${ }^{40}$ : "Two thirds of the mothers had low vitamin $\mathrm{B}_{12}$ concentrations, folate deficiency was rare, and high circulating concentrations of homocysteine predicted IUGR" [Italics mine]. It cannot be overemphasized that such a conclusion from this dedicated nutrition group in India is both erroneous and misleading to less specialized healthcare givers at large. [Parenthetically, prospective longitudinal follow up after individual serial vitamin-replacement can unambiguously answer the question of the frequency with which the serum folate can fail to rise into the normal range in such populations with combined vitamin- $\mathrm{B}_{12}$ and folate deficiency].

2. Pregnant women in India. Folate deficiency during pregnancy arises from a combination of poor dietary folate intake, increased requirements for maternal-fetal growth, and increased losses. ${ }^{1,6}$ The majority (more than $90 \%$ ) of women of reproductive age in resource-limited countries (from sub-Saharan Africa, South and South East Asia, and Latin America) consume less than the estimated average requirement of folate, ${ }^{4}$ which predisposes them to folate deficiency before, during, and after pregnancy. By the late 1960s using microbiological blood tests for serum folate, folate deficiency was diagnosed among $85-100 \%$ of Nigerian, ${ }^{41}$ up to $80 \%$ of Canadian ${ }^{42}$ and $73 \%$ South Indian women ${ }^{43}$ in the third trimester of pregnancy. Parenthetically, if these South Indian women also had metabolic evidence of vitamin- $\mathrm{B}_{12}$ deficiency - which we now know to be a worldwide problem ${ }^{7,33,36,37,44}$ - the finding of a below- 
normal serum folate concentration in these women would actually reflect severe tissue folate deficiency.

But do South Indian women consume less folate then their sisters in North India? The estimated dietary intake of folate among women in Northeastern and Eastern States in India is only 75 - to $168-\mu \mathrm{g} / \mathrm{day}^{45}$; these values range from one-fifth to one-third of the optimum needed to prevent neural-tube defects. ${ }^{1,6}$ Despite these facts, among 283-pregnant women (one-half who were less than 22-years old) from rural Haryana in North India, 68\% had iron deficiency, 74\% had vitamin- $B_{12}$ deficiency, but only $26 \%$ apparently had folate deficiency based on blood tests. ${ }^{46}$ The implied conclusion was that vitamin- $\mathrm{B}_{12}$ deficiency is more of a threat than folate deficiency. ${ }^{46}$ But since vitamin- $B_{12}$ deficiency was also present, many of those women with mildto-moderate tissue folate deficiency could be expected to have serum folate concentrations in the 'normal' range. ${ }^{17}$ An earlier study from this region ${ }^{47}$ noted that "the consumption of food groups rich in micronutrients (pulses, vegetables, fruits, nuts and oil seeds, animal foods) was infrequent"; that "99\% of these women consumed less than one-half of the recommended folic acid" 46 ; that "over $19 \%$ pregnant women were consuming less than $50 \%$ of the recommended calories", ${ }^{47}$ and $60 \%$ of pregnant women consumed less than $75 \%$ of recommended daily caloric allowance "indicating an overall poor food intake". ${ }^{46}$ Such levels of poverty strongly correlate with and support the likelihood of low-folate status. ${ }^{1,6}$ Moreover, the state of Haryana is adjacent to Delhi-where both affluent city-folk and neighboring slum-dwellers were also documented to have equally poor dietary intake of folate and vitamin- $\mathrm{B}_{12}$, with high homocysteine values of 23to $25-\mu \mathrm{M}$ among $88 \%$ of study subjects. ${ }^{48}$ Again, such results were likely due to a combination of folate plus vitamin- $\mathrm{B}_{12}$ deficiency because more than $90 \%$ of both groups consumed less than one-fifth of optimum folate, and more than $75 \%$ consumed less-than-optimum amounts of vitamin- $\mathrm{B}_{12}$ daily. ${ }^{48}$ Therefore it is likely that many of those pregnant women from rural Haryana 
${ }^{46}$ had a combined vitamin- $\mathrm{B}_{12}$ plus folate deficiency (with the latter masked by extant vitamin$\mathrm{B}_{12}$ deficiency). So it should be stressed that folate deficiency is pervasive among women in both South and North India.

These case studies illustrate how the use of biomarkers of serum folate without due consideration of the prevailing nutritional intake of folate and vitamin- $\mathrm{B}_{12}$ has led to a systematic de-emphasis of the issue of masked folate deficiency (within the context of widespread vitamin$\mathrm{B}_{12}$ deficiency). This can continue to perpetuate the wrong concept that folate deficiency is not a serious problem among women residing in resource-limited countries. Moreover, any consequent reduction in vigilance over the need for folate supplements for young girls well before they become pregnant has the dangerous potential to perpetuate maternal folate malnutrition with serious consequences to maternal-child morbidity and mortality. ${ }^{49}$

Limitation of the serum folate biomarker in the setting of hemolysis (malaria) $=a$ historical perspective. In 1961, Waters and Molin $^{50}$ observed: "[It] was found that varying degrees of hemolysis increased the folic acid activity from three to ten times that of unhaemolysed serum". By 1966, Hoffbrand et al ${ }^{22}$ documented a 30-fold higher erythrocyte folate to serum folate ratio in normal individuals. Therefore profound hemolysis during the erythrocytic stage of Plasmodium falciparum, which infects erythrocytes of all ages including bone marrow orthochromatic erythroblasts, ${ }^{51}$ will release their 30 -fold higher folates into serum. ${ }^{22}$ In vitro hemolysis can also occur during blood collection, transportation, or storage arising from inadequate resources and/or infrastructure in malarious areas..$^{52,53}$

Intravascular hemolysis of parasitized cells and hypersplenism induces a powerful stimulus for compensatory erythropoiesis, ${ }^{54,55}$ increasing basal erythrocyte-production rates (of 2million per second in humans) by 5- to 10 -fold, leading to significant reticulocytosis. However, over 50-years ago, Herbert and Zalusky ${ }^{14}$ reported that reticulocytes are richer in folate than 
mature erythrocytes; thus $26 \%$ reticulocyte-rich preparations had nearly 10 -fold increases in folate content than $6 \%$ reticulocyte-poor preparations (i.e., 273-ng/ml versus $29-\mathrm{ng} / \mathrm{ml}$, respectively). Parenthetically, the physiological basis for higher folate content of reticulocytes and erythroid precursors was determined over two decades later in my laboratory. ${ }^{56-58}$ Both reticulocytes and mature erythrocytes contained vestigial remnants of functional folate receptors that primarily mediated the uptake of folate into erythroid precursors within bone marrow. ${ }^{58}$ Thus, in the presence of compensatory erythrocytosis and reticulocytosis associated with hemolysis, analysis of such reticulocyte-rich blood for erythrocyte folate content (RBC folate concentration) would yield high values; this could give a false impression of normal folate status, when in fact, the true folate status may be low because of a combination of poor dietary folate intake and increased folate requirements to support compensatory hematopoiesis (Table 1). (The extent of contribution to the red cell folate content from Plasmodium falciparum, which can synthesize folates in erythrocyte cultures in vitro ${ }^{59}$ and also raise erythrocyte folates in animal models with high levels of parasitemia ${ }^{60}{ }^{6}$ is unknown in humans). So measurement of the serum folate level in malaria during hemolysis of Plasmodium falciparum-infected erythroid precursors, reticulocytes, and mature erythrocytes, with release of folate-rich intra-erythrocyte contents (and an as yet unknown quantity of liver folate) into serum, would also provide misleading estimates of the patient's folate status. In this context, there would be added complexity because repeated cycles of Plasmodium falciparum-induced hemolysis would release substantial amount of various forms of folate-i.e., 5-methytetrahydrofolate [monoglutamates] and folate polyglutamates of different glutamate chain lengths ${ }^{61}-$ into the serum. Apart from the poor clearance of serum 5-methyltetrahydrofolate that is associated with vitamin- $\mathrm{B}_{12}$ deficiency $^{19}$ (Figure 1), polyglutamylated-folates are also inefficiently transported back into cells relative to monoglutamates. ${ }^{1,62}$ However, because the earlier microbiological assays for folate could not 
discriminate between these various forms of folates ${ }^{22,50}$ a high serum folate would be reported in all these individuals (Table 1).

Populations living in resource-limited malarious regions of Asia and Africa often suffer from food insecurity, which predicts for poverty-imposed near-vegetarianism ${ }^{1,67}$; this involves consumption of a monotonous, largely vegetarian or vegan-like diet that is low in folate, iron, and vitamin- $\mathrm{B}_{12}{ }^{7,37,44,63}$ Here too, the coexistence of vitamin- $\mathrm{B}_{12}$ deficiency in these populations will also raise the serum folate concentration.

There is no prior human data that has systematically evaluated the effects of repeated cycles of Plasmodium falciparum-induced hemolysis on serum folate levels; however, given the longstanding mandate of administering prophylactic folate supplements for all patients with hemolysis ${ }^{1,6}$ it would be unethical to prospectively conduct such studies. Nevertheless, because evidence-(i.e., 30-fold higher erythrocyte folate; hemolysis of folate-rich erythrocytes, reticulocytes, and orthochromatic normoblasts during the erythrocytic phase of malaria; and associated vitamin- $\mathrm{B}_{12}$ deficiency)-does compound, ${ }^{64,65}$ there is a high probability that in resource-limited settings associated with food insecurity-imposed inadequate vitamin- $\mathrm{B}_{12}$ and folate intake, a patient with profound hemolysis from Plasmodium falciparum malaria will still have an artificially high [or normal] serum folate concentration despite extant nutritional [tissue] folate deficiency.

With this background, we are in position to critically evaluate the veracity of conclusions from influential studies that measured serum folates in African children with malaria and/or vitamin- $\mathrm{B}_{12}$ deficiency and [erroneously] concluded that folate deficiency is uncommon, even though their diet was severely compromised by dire poverty and/or famine.

Masking of folate deficiency by malaria (and probable nutritional vitamin- $B_{12}$ deficiency)

(i) Children in The Gambia. Abdalla et a ${ }^{66,67}$ observed that "the serum and red cell folate levels 
were above the lower limits of normal" among 75 of 106-Gambian children less than 5-years with acute uncomplicated Plasmodium falciparum malaria and variable degrees of anemia. These investigators therefore concluded that folate deficiency was not likely given these laboratory values. Unfortunately however, they failed to make connections between the potential for malaria-induced hemolysis and reticulocytosis to raise the serum and red cell folate concentration independently of the folate status of these children. But were these children well nourished and consuming a well-balanced diet that was rich in folates? To the contrary, historical records ${ }^{68}$ reveal that there was a very high likelihood of severe food insecurity in The Gambia during this period. For example, Abdalla et al conducted their series of studies during harsh, recurrent droughts of the 1970's and 1980's (known as the [African] 'Sahel Desiccation') that included The Gambia, which resulted "...in massive losses of agricultural production and livestock; loss of human lives to hunger, malnutrition and diseases; massive displacements of people and shattered economies" ${ }^{68}$ So there was evidence of severe food insecurity, which predisposes to poor dietary intake of micronutrients (folate plus vitamin- $\mathrm{B}_{12}$ ) and iron. ${ }^{7,37,44,63}$ Yet, without considering $\underline{a}$ ) the high red cell folate concentrations in reticulocyte-rich blood, or $\underline{b}$ ) the role of hemolysis of Plasmodium falciparum infected erythroid precursors, reticulocytes and erythrocytes in increasing the serum folate, or $\underline{c}$ ) the likelihood of associated dietary vitamin- $\mathrm{B}_{12}$ deficiency in artificially raising the serum folate ${ }^{22,50,52,53}$ or $\underline{d}$ ) the need to provide folate to support compensatory hematopoiesis (the prevailing dictum ${ }^{8,13}$ ), or $\underline{e}$ ) the extant poor nutritional status of these children, these investigators (hematologists) did not recommend folate supplements. As a result, other clinicians and nutritionists have been misled by a fallible laboratory test over other indicators of folate deficiency. These influential studies ${ }^{66,69-71}$ have led to an across-the-board conclusion that tens-of-millions of other children with chronic hemolysis from repeated episodes of malaria and a poor dietary intake of folate do not have folate 
deficiency. ${ }^{71,72}$ Equally surprising, is the fact that innumerable papers and authoritative reviews on anemia in malaria ${ }^{73,74}$ have not even considered the likelihood of poor micronutrient intake as a contributing factor to anemia in these populations. As a consequence, there has been no mandate from the medical establishment for giving such children folate despite their likely need of this vitamin.

(ii) Children in Malawi. In a high-profile paper, Calis et $a l^{75}$ found severe anemia in Malawian children where malaria was found in $60 \%$ and vitamin- $B_{12}$ deficiency in $30 \%$ "[but] folate and iron deficiencies are not prominent". In response to the issue of extant poor diet, poor testsensitivity, and hemolysis in underestimating folate deficiency [raised in correspondence ${ }^{76}$, the authors acknowledged: "[It] is theoretically possible that hemolysis and vitamin- $\mathrm{B}_{12}$ deficiency have masked folate deficiency.... We did not evaluate the source of dietary-folate intake in these children in detail, but green vegetables and fruits account for a large proportion of the dietary intake of children in Malawi...". ${ }^{75,76}$

However, this rosy dietary assessment among children in Malawi-the seventh poorest country in the world-is contradicted by reports from three different sources that highlight the nutritional status of the population at that time:

(a) A Food and Agriculture Organization report, ${ }^{77}$ which highlighted two droughtinduced famines in the 1990s and in the year immediately preceding and following the 20022004 study by Calis et al, ${ }^{75}$ concluded with a poignant description of serious malnutrition among Malawian children less than 5-years - the age group studied ${ }^{75}$ : “...[p]overty and food insecurity explain the very high prevalence of chronic malnutrition that plagues Malawi, almost half of the children under-five years being stunted... Micronutrient deficiencies are widespread.... The nutritional status of the Malawian population remains critical". ${ }^{77}$ 
(b) An earlier study on the impact of malarial infection and diet on anemia in rural pregnant Malawian women in 1999 noted $^{78}$ : "Cereals, predominantly maize, provided more than $75 \%$ of energy in their diets. Maize flour has a very low folate content (that is $25-\mu \mathrm{g} / 100-\mathrm{gm}$ ). It is consumed two to three times a day, often as a stiff porridge (nsima) with a cooked relish prepared from green leaves (for example pumpkin leaves) or legumes. However, because the traditional Malawian cooking practices involve protracted boiling, much of the folate in the cooked relishes is probably destroyed".

(c) The intergenerational (mother-to-child) transmission of micronutrient deficiency has a profound impact on children. Among 150-anemic Malawian women predominantly in the third trimester ${ }^{79}$ folate deficiency was found in only $34 \%$, and vitamin- $\mathrm{B}_{12}$ deficiency in $33 \%-(80 \%$ of whom also had normal serum folates). However, a then-contemporary Malawian report in 2000 noted the serious food insecurity and famine-like conditions of the nineties, and concluded" ${ }^{80}$ : Young children and women of reproductive age are especially vulnerable to nutritional deficits and micronutrient deficiency disorders". Because folate-rich foods are not easily available ${ }^{78}$ and consumption of folate supplements during socio-economic upheavals of famine are uncommon, ${ }^{1,6}$ it is quite unlikely that these Malawian women consumed a folate-rich diet sufficient to avoid folate deficiency during the third-trimester. So how can one explain the observed 'normal serum folate levels' among two-thirds of this pregnant population? ${ }^{79}$ Here, it is particularly significant that these authors noted ${ }^{79}$ : "The diet of most women in our situation is effectively vegan". Although such vegan diets are notoriously low in vitamin- $\mathrm{B}_{12}$ content mandating routine prophylactic vitamin- $\mathrm{B}_{12}$-supplementation, ${ }^{1,718-83}$ this was not routine practice in Malawi. ${ }^{79}$ Therefore, it is likely that a greater number of these Malawian women ${ }^{79}$ would have been diagnosed with vitamin- $\mathrm{B}_{12}$ deficiency if more sensitive [metabolite] studies of serum methylmalonic acid and homocysteine were used..$^{7,33,36,44,63}$ And many more women with 'normal' 
serum folate in that study ${ }^{79}$ likely had masked tissue folate deficiency. Such women would invariably pass down their own folate/vitamin- $\mathrm{B}_{12}$ deficiency to their babies, who continue to consume folate/vitamin- $\mathrm{B}_{12}$-poor breast milk $^{35,84,85}$ before being weaned onto similar diets as their mothers.

So how did those little Malawian children in the study by Calis et $a l^{75,76}$ - who needed folate to support compensatory hematopoiesis and were in the midst of near-famine conditions in Malawi $^{77,79}$-acquire folate and avoid folate deficiency if their mothers were not getting sufficient vitamin- $\mathrm{B}_{12}$ or folate? The body of evidence cited ${ }^{77-79}$ is contrary to the assertion that an abundant folate-rich diet consumed by those children can explain findings of "normal serum folate' values in their patients. ${ }^{75,76}$ Yet, the conclusion that folate deficiency is not a problem in patients with malaria ${ }^{75}$ (which mimic earlier conclusions ${ }^{66,69-72}$ ) is now widely viewed as factual: The authoritative UpToDate® entry on 'Anemia in Malaria', ${ }^{74}$ which highlighted the work of Abdalla $^{67}$ and Calis et $a l,{ }^{75}$ concluded that folate deficiency is uncommon ${ }^{74}$ : "Although dietary deficiencies are widespread in malarial endemic regions the influence of reduced folate levels [sic] are not thought to be major contributors to the dyserythropoiesis seen during severe malarial anemia. ${ }^{67}$ The finding of low vitamin $B_{12}$ levels in malaria suggests that subclinical deficiency of $\mathrm{B}_{12}$ may play a hitherto unrecognized contribution to severe anemia... ${ }^{75},-[$ Italics mine $]$.

(iii) Children in Kenya. The case from Embu, Kenya, is instructive because both vitamin- $\mathrm{B}_{12}$ deficiency and Plasmodium falciparum malaria were endemic in the region. ${ }^{86}$ Among children aged 5- to 14-years, $31 \%$ had serum vitamin- $\mathrm{B}_{12}$ levels less than $125-\mathrm{pmol} / \mathrm{L}$ (severe vitamin- $\mathrm{B}_{12}$ deficiency) whereas $38 \%$ had serum vitamin- $\mathrm{B}_{12}$ values between 125-220-pmol/L (moderate vitamin- $\mathrm{B}_{12}$ deficiency). Although one-third had malaria, $45 \%$ had enlarged spleens (suggestive of chronic malaria re-infection). However, the prevalence of folate deficiency based on serum folate levels was almost zero! (The actual values for serum folate were between 20-46-nmol/L 
with the upper value at the upper limit of the assay). Of significance, the potential role of vitamin- $\mathrm{B}_{12}$ deficiency or malarial-hemolysis in artificially raising serum folate (thereby masking an underlying folate deficiency) was not considered.

Taken together, despite the known limitations of the blood tests for folate in the presence of vitamin- $\mathrm{B}_{12}$ deficiency and/or hemolysis accompanying malaria, there has been a consistent undue overreliance on these imperfect blood tests, even over the more reliable estimates from poor dietary folate intake and other clinical indicators of folate deficiency (discussed below). Because the results of such blood tests invariably trigger decisions for [or against] replacement therapy, the interpretation of results following the measurement of the serum folate level in these patients has, in all likelihood, resulted in the therapeutic decision to [continue to] withhold folates from these unfortunate women and children, thereby predicting an adverse outcome.

\section{Tracing the potential cognitive biases in medicine that may have led to propagation of an}

error in the literature. How could the medical establishment have $\underline{a}$ ) ignored the well-known facts related to the masking of the serum test for folate deficiency in the presence of vitamin- $\mathrm{B}_{12}$ deficiency and hemolysis accompanying malaria? And $\underline{b}$ ) fallen prey to the false concept that folate deficiency is rare in resource-limited countries where dietary intake of folate and vitamin$\mathrm{B}_{12}$ is poor, and anemia and malaria is endemic? Here we must confront our collective cognitive biases that have likely led to perpetuation of the medical myth exposed in this article.

Whenever a high-profile paper in the literature downplays key results from earlier papers, subsequent papers tend to highlight the more recent paper and exhibit "recency bias", wherein a disproportionate importance is given to more recent observations and conclusions. ${ }^{87}$ This has, and will in turn, lead to an "availability bias/cascade" - a self-reinforcing process ${ }^{87}$ wherein the collective beliefs of researchers appears more and more plausible through repetition of the same fact over and over again in high-profile journals. [Even Kipling's Bandar-log had a similar 
slogan: "We all say so, so it must be true" ${ }^{98}$ ]. Intrinsic to the process of dissemination of medical information is the "framing effect", which (in the context of this paper) involves drawing different conclusions from the same information in a dataset, depending on the author's choice of presentation. ${ }^{87}$ So when a normal-to-increased serum folate level is observed in vitamin- $\mathrm{B}_{12}$ deficiency, the potential of masked folate deficiency has been ignored. ${ }^{36,46}$ Likewise the findings in Gambian and Malawian children with malaria and normal-to-high serum folate levels have subsequently led to broader conclusions that almost all African children with malaria do not have folate deficiency. ${ }^{89}$ Then, as more and more experts from several diverse specialties - including obstetrics,${ }^{90}$ nutrition, ${ }^{36}$ infectious disease,${ }^{91}$ internal medicine,${ }^{92}$ pediatrics,${ }^{69,93}$ cardiology ${ }^{94}$ endocrinology, ${ }^{95}$ epidemiology and public health, ${ }^{92}$ and $\underline{\text { even }}$ hematology ${ }^{72,73}$ - studied populations at risk for both vitamin- $\mathrm{B}_{12}$ deficiency and malaria without sufficient consideration of all clinically relevant data including the dietary history, they referenced those papers that supported their own observations, and viewed the results from these cohorts through the narrow lens of their individual specialty. This reflects a "confirmation bias" - the tendency to search for or interpret the information of their own research in a way that confirms earlier preconceptions. ${ }^{87}$ When confirmation bias reaches epidemic proportions,${ }^{87}$ this can lead to in-group bias; here reviewers of papers proffered to Journals can tend to preferentially accept those papers that reinforce the conclusions by several other members of their own group. Not surprisingly, further propagation of the concept among groups of researchers (now reading similar journals) will invariably lead to a "bandwagon effect" where many more individuals believe the same thing ${ }^{87}$ this is closely related to groupthink and herd behavior.$^{87}$ The danger of groupthink is particularly germane to various reviews or even consultations periodically held by major agencies (e.g., National Institutes of Health, World Health Organization, \& Etc.) to generate "White Papers" on state-of-the-art. Minimization of controversy or conflict within this construct can fail to critically 
assess the data that led to the conclusions in the first place, with a group-wise failure in accepting any alternative proffered ideas, views, or concepts.

Defining tissue folate deficiency in resource-limited countries - caveats and limitations. Because the liver parenchyma is the primary site for storage of folates ${ }^{1}$, depletion of the amount of folate in the liver indicates folate deficiency; however a liver biopsy is much too invasive a test for routine clinical use. Given the limitations in interpretation of serum folate tests in resource-limited settings (as discussed above), can a study of other clinically accessible tissues help to confirm deficiency and perhaps distinguish it from vitamin- $\mathrm{B}_{12}$ deficiency? Although the test for RBC folates (by microbiological assay) was a good surrogate test for pure tissue folate stores, the newer non-microbiological assays for RBC folates have not been as clinically reliable (as discussed above). Moreover, in the context of a patient infected with malaria there are additional problems in interpretation of RBC folates. This stems from the fact that the malarial parasite has a life cycle that involves both an erythrocytic and an exo-erythrocytic phase (in liver) that results in hemolysis of red cells and lysis of infected parenchymal liver cells, respectively. And parasites themselves can contribute an [incompletely characterized] amount of folate to infected red cells. ${ }^{59,60}$ This further limits the value of [serum and] RBC folates. So can an analysis of the bone marrow morphology [following a bone marrow aspirate/biopsy] identify megaloblastic anemia associated with folate deficiency? Yes, provided there are no other confounding variables. But in the case of associated malaria, information on the extent to which parasitic infestation per se modulates the morphological expression of folate deficiency in these tissues is limited to published data [on the morphology of bone marrow aspirates] from only a handful of children in The Gambia. ${ }^{66,67}$ Because such studies were carried out during famine conditions (the Sahel Dessication), these children were likely to have had varying grades of multiple combined deficiencies of minerals (predominantly iron, but also zinc, copper, and 
selenium) and micronutrients (including folate and vitamin- $\mathrm{B}_{12},-\mathrm{A},-\mathrm{B}_{1}$, and $-\mathrm{B}_{6}$ ). (Parenthetically the likelihood of multiple deficiencies in these children was not commented on in these publications). ${ }^{6,67}$ Collectively, these multiple deficiencies can be expected to significantly alter the morphology of folate-deficient megaloblastic anemia. As one example, we know that associated iron deficiency will significantly modify and mask the [expected] classic features of megaloblastic anemia (i.e., masked megaloblastosis) ${ }^{1}$; instead, finding other subtle manifestations of giant myelocytes and metamyelocyte and hypersegmented polymorphonuclear leukocytes are clues that can clinch the diagnosis. [Therefore preclinical studies that can precisely clarify the independent and combined impact of additional mineral and micronutrient deficiencies in modifying the expected features of megaloblastic anemia, and how this is further altered in malaria-infected bone marrow, are areas for additional study]. Finally, merely identifying megaloblastic anemia cannot distinguish between folate or vitamin- $\mathrm{B}_{12}$ deficiency. ${ }^{1}$ Thus, the challenge to unambiguously diagnose single deficiency of folate or vitamin- $\mathrm{B}_{12}$ from combined vitamin- $\mathrm{B}_{12}$ and folate deficiency necessarily rests on the cumbersome and expensive serial measurement of metabolites (methylmalonic acid and homocysteine) after specific replacement of the deficient vitamin (as discussed above). But by the same token, mere use of a single metabolite test result to exclude the coexistence of folate deficiency warrants far greater caution in interpretation than exhibited in the publications cited.

\section{Alternative methods for assessing folate status in resource-limited settings. Dietary} assessment using a variety of methods (24-h recall, estimated/weighed record, or locally validated food-frequency questionnaires ${ }^{96-98}$ ) are established methods to evaluate the quality of food and quantity of nutrients consumed by individuals in an ethnically homogeneous area. ${ }^{4,99}$ Despite intrinsic limitations, these methods can predict with fair reliability the dietary folate and vitamin- $\mathrm{B}_{12}$ intake of a larger population consuming similar foods, and identify those at risk for 
nutritional insufficiency. ${ }^{4,48,48,96-98,100}$ These approaches allow for the conclusion that there is inadequate dietary-folate intake and widespread folate deficiency throughout India, which is also associated with both iron and vitamin- $\mathrm{B}_{12}$ deficiency. ${ }^{35,45,48,96,101}$ Such information contributed to raising the recommended dietary allowance for folate intake in India to $250-\mu \mathrm{g} / \mathrm{day}$ in $2010 .^{102}$ Similar approaches can be used in other resource-limited countries.

On the consequences of underestimating poor folate status in women and children. Anemia is the most common clinical manifestation of a deficiency of iron-, folate-, and vitamin- $\mathrm{B}_{12}$ (in various combinations); is widespread among children, adolescents, and women throughout India ${ }^{103,104}$; is believed to be among the highest in the world ${ }^{101,105,106}$; and can lead to serious maternal morbidity and mortality. ${ }^{49,107-110}$ Likewise, the relatively monotonous diet of women and children and the accompanying food insecurity in Africa-in Kenya, ${ }^{97,100,111,112}$ Malawi, ${ }^{77,78,80}$ and The Gambia ${ }^{68}$ that predisposes them to clinically significant deficiencies of iron, folate and vitamin- $\mathrm{B}_{12}{ }^{7,37,44,63}$-also manifests as widespread nutritional anemia. ${ }^{103}$ In this context, it should be noted that attempts to replenish either iron and/or vitamin- $B_{12}$ without addressing existing folate deficiency would invariably result in persistent anemia.

Although there are many causes for neural-tube defects, the vast majority of these defects can be prevented by periconceptional folate supplements ${ }^{1,6,113-115}$ with greater protection (up to $70 \%$ ) afforded when the incidence of neural-tube defects is higher.${ }^{114}$ Based on both preclinical studies ${ }^{116-119}$ and clinical trials ${ }^{13,114}$, the relationship between folate replacement and prevention of neural-tube defects fulfills Koch's postulates on the causation of disease. ${ }^{120}$ Therefore the value of optimizing folate status is self-evident. But is this a problem in India? The only populationbased approach reported from a cluster of villages in North India discovered the incidence of neural-tube defects was $6 \cdot 57$ - to $8 \cdot 21$ - per 1000 -live births, ${ }^{121}$ which is among the highest in the world. Although our study was from the least-developed area of India ${ }^{121}$, this region was 
representative of 168 additional districts in India, and the incidence of neural-tube defects was similar to that recorded in tertiary centers from several major cities in North and South India ${ }^{122-}$ ${ }^{124}$; this somewhat validates extrapolation of the incidence of neural-tube defects to a much wider area in India. ${ }^{121} \mathrm{~A}$ recent systematic review has identified a birth prevalence of neural-tube defects in India of $4 \cdot 1$ per 1000 -births, ${ }^{125}$ reflecting a largely silent epidemic of mammoth proportions. ${ }^{121,126}$ Therefore, using data from the lower and higher incidence of neural-tube defects $(4 \cdot 1$ - to $8 \cdot 21$ - per 1000 -births), and conservative estimates on potential prevention of onehalf of neural-tube defects with periconceptional folate supplements ${ }^{114}$-based on an estimated 27-million annual pregnancies in India - there could well be between 55,000- to 110,000-births with neural-tube defects that can be prevented each year by optimizing folate status. This is a critically important opportunity for governmental leaders to rectify ${ }^{2}$ and thereby reduce the incalculable physical, psychological and economic burden for affected children and their families.

(Despite the strength of the data underlying the prevention of neural-tube defects with folate supplementation, because of the close metabolic interrelationship between folate and vitamin- $B_{12}$, it is possible-(but not yet unambiguously proven clinically) - that vitamin- $B_{12}$ deficiency will also be independently shown as a cause of neural tube defects. ${ }^{127}$ Clinical investigations into the potential role of vitamin- $\mathrm{B}_{12}$ deficiency as an independent risk factor in neural-tube defects - based on low vitamin- $\mathrm{B}_{12}$ levels in mothers of affected progeny-will necessarily need to rule out an associated [masked] folate deficiency. So despite the apparent high prevalence of vitamin- $\mathrm{B}_{12}$ deficiency, it is not yet possible to attribute a precise risk percentage of vitamin- $B_{12}$ deficiency to neural-tube defects in India).

Prophylactic administration of folate to women of childbearing age can prevent shortterm pregnancy complications (anemia, abruptio placenta, small-for-date babies, preterm birth), 
as well as adverse short-term pregnancy outcomes for the newborn (low birthweight, midline birth defects). ${ }^{128}$ Recent studies from UK, Norway, Sweden, and India-where governmentmandated folate fortification of food is not in practice-also suggest that the progeny of women who do not consume folate supplements during the periconceptional period can exhibit subtle long-term adverse consequences in behavior during childhood. ${ }^{129-132}$ Parenthetically, these observations are the human correlates of earlier preclinical studies (in mice), ${ }^{133,134}$ which confirmed a relationship between gestational folate deficiency and abnormal neuro-pathology and neuro-development in utero. Our subsequent studies suggest a novel molecular basis for the aberrant activation of such neurological pathways in the fetal brain that experiences gestational folate deficiency; this involves the post-translational homocysteinylation of an mRNA-binding protein that abnormally modulates the expression of proteins that are involved in the biosynthesis of both neurotransmitters and neurons. ${ }^{1,6,135}$ This is yet another area that warrants additional study.

Appropriate prophylaxis negates laboratory testing for folate deficiency. The mandate for folate supplementation of patients with hemolysis originally arose in the West, where despite consumption of an apparently folate-sufficient diet, patients with different etiologies for hemolysis often developed folate deficiency that led to an aplastic crisis. ${ }^{8,13}$ This hemolysisinduced folate deficiency predictably arises from increased requirements to support compensatory hematopoiesis in the bone marrow and chronic loss of red cell folates into the urine and stool. Therefore a longstanding dictum in clinical hematology is that all patients with hemolysis from any cause must be given 1-mg folic acid/day to optimize hematopoiesis, because a failure to do so can precipitate a reticulocytopenic [megaloblastic] crisis. ${ }^{1,6}$ [Additional causes for hemolysis in patients with malaria that warrant routine folate supplements include: hemoglobinopathies that confer resistance to malaria ( $\alpha$ - or $\beta$-thalassemia, sickle cell disease); 
individuals with glucose 6-phosphate dehydrogenase-deficiency given primaquine, sulfadoxine, or dapsone for malaria; a Coombs-positive immune-mediated hemolysis; and sepsis-induced disseminated intravascular coagulation]. Parenthetically, and in this context, among populations where the dietary intake of folate, vitamin- $\mathrm{B}_{12}$, and iron is compromised, it is unknown how frequently the reticulocytopenia observed in Plasmodium falciparum-anemia ${ }^{74}$ can be reversed with folate plus vitamin- $\mathrm{B}_{12}$ plus iron supplements. As noted above, it is possible that other associated micronutrients and mineral deficiencies can profoundly alter hematopoiesis in the bone marrow. Nevertheless, there has been no controlled clinical trial that has unambiguously shown that such children did not benefit from replacement doses of folic acid administered with antimalarials after iron and/or vitamin- $\mathrm{B}_{12}$ deficiency is reversed. Therefore until such data is available, children suspected of having such micronutrient deficiencies ought to be given the benefit of such replacement.

A related axiom in clinical medicine is that there is little point in performing any test if the result does not change one's therapeutic decision. Therefore a relevant question is: "Why is it necessary to know the folate status of an individual with active malaria, since all such patients ought to be given folate to support compensatory hematopoiesis (together with antimalarials)?" Indeed, one can make a strong case that in clinical practice in resource-limited settings the use of blood tests to assess for folate status during hemolysis has no basis.

But are there risks to administering folate supplements to support compensatory hematopoiesis in malaria? A recent meta-analysis of 19 studies have put to rest the concern of iron-folate and malarial progression ${ }^{136}$ and a Cochrane analysis identified no evidence that this is a problem when combined with antimalarial drugs and insecticide-treated bed-nets. ${ }^{137}$

Although Plasmodium falciparum possess two folate transporter proteins that can facilitate membrane transport of folic acid, folinic acid, the folate precursor p-amino benzoic 
acid (pABA), and the human folate catabolite $\mathrm{pABAG}_{\mathrm{n}}$, rescue experiments on parasites in vitro show that pABA was the only effective salvage substrate at normal physiological levels. ${ }^{138}$ Recently Van Eijk et al ${ }^{139}$ affirmed the safety of low-dose folic acid (1-mg/day) in 467-pregnant women with malaria; however, high-dose folic acid (5-mg/day) will allow for resistance, and have adverse outcomes in children..$^{140-142}$

Therefore given their propensity to have multiple deficiencies that continue into pregnancy, all non-pregnant women who require anti-malarial treatment ${ }^{143}$ should be treated for both malaria as well as iron, folate, and vitamin- $\mathrm{B}_{12}$ to enable optimal hematopoiesis. Likewise, all pregnant women living in resource-limited malarious areas malaria should routinely be given intermittent preventive treatment according to the latest guidelines (currently it is sulfadoxinepyrimethamine ${ }^{144}$ ) together with insecticide-treated bednets, plus 1-mg folic acid, prophylactic doses of 10 - to $25-\mu \mathrm{g}$ vitamin- $\mathrm{B}_{12}$ and replacement doses of iron orally. ${ }^{145}$

Finally, optimizing the nutrition and general health of young women well before they are pregnant (i.e., intentional preparation for pregnancy ${ }^{146}$ ) is also the best way to ensure optimum transfer of nutrients to the developing fetus, and to nurture the baby after delivery. Indeed, this is the only way to curtail the inter-generational passage of these mineral and micronutrient deficiencies from mother to baby ad infinitum.

\section{Conclusion}

The repetition of a critical error involving the misinterpretation of a blood test result in the clinical literature in populations at risk for combined folate- and vitamin- $\mathrm{B}_{12^{-}}$deficiency and/or malaria has led to a 'snowball effect' wherein paper-upon-paper has propagated the myth that folate deficiency is uncommon in resource-limited settings. As a result, millions of women and children with true [tissue] folate deficiency have probably not been given folate replacement. It is hoped that recognition and redress of such serious errors among women and children in these 
resource-limited settings - that can be achieved by early prophylactic replenishment with micronutrients that include folate and vitamin- $\mathrm{B}_{12}$ (and key minerals) - will improve maternalchild health and reduce the unacceptably high morbidity and mortality in these regions.

Conflict of Interest Statement: There is no conflict of interest to declare. Dr. Antony is solely responsible for the written content of this manuscript.

Acknowledgement of support: Dr. Antony practices Medicine at Indiana University Affiliated Hospitals and is a tenured faculty member of Indiana University. His basic science laboratory is supported by extramural (Federal) research grants. Neither the University nor any Federal agency had a role in selecting the information presented. 
Legend to Figure 1: Vitamin-B ${ }_{12}$ and folate interrelationships: Normally, the tissue utilization of serum 5-methyl-tetrahydrofolate requires vitamin- $\mathrm{B}_{12}$ (as methyl-vitamin- $\mathrm{B}_{12}$ [also known as methyl-cobalamin]) to activate methionine synthase, a key enzyme that converts 5-methyltetrahydrofolate to tetrahydrofolate, which is then polyglutamylated by folylpolyglutamate synthase (not shown in the figure). These folate polyglutamates are thereby retained in the cell and are the forms that participate in and perpetuate one-carbon metabolism. But with vitamin- $\mathrm{B}_{12}$ deficiency, there is lowered activity of methionine synthase, which results in a functional folate deficiency wherein an increased amount of 5-methyl-tetrahydrofolate-(and homocysteine that is not methylated by methionine synthase to form methionine) - is trapped and accumulates within cells. Because 5-methyl-tetrahydrofolate is a poor substrate for folylpolyglutamate synthase, there is decreased synthesis of folate polyglutamates. As a result 5-methyltetrahydrofolate (and homocysteine) leaks out of cells into blood. ${ }^{1,21}$ When vitamin- $\mathrm{B}_{12}$ deficiency is prolonged, there is a real cellular folate deficiency arising from failure to retain folate within cells. ${ }^{21}$ This explains why patients with pernicious anemia and/or nutritional vitamin- $\mathrm{B}_{12}$ deficiency have normal to high serum folates (that can mask an associated mild-tomoderate folate deficiency) and high serum homocysteine levels, and an initial functional intracellular folate deficiency that culminates over time in a true tissue folate deficiency, and low erythrocyte folates.

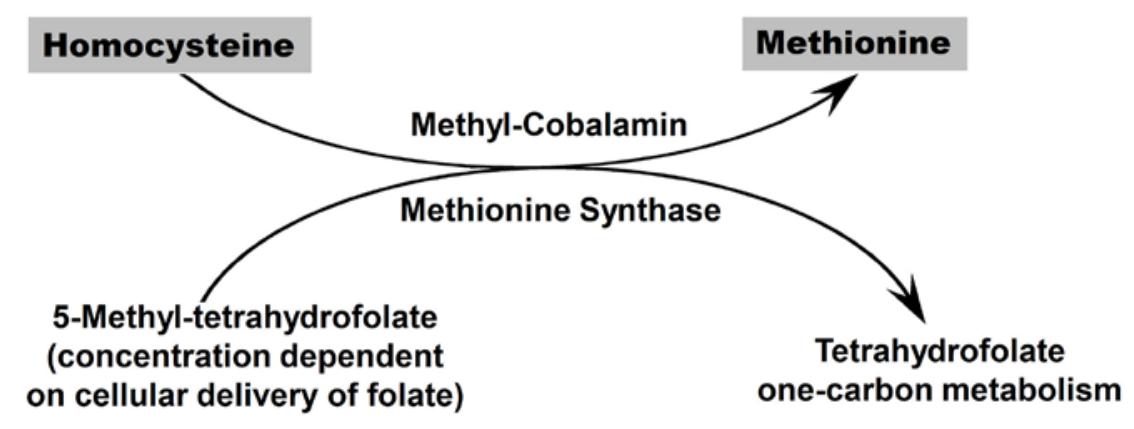




\section{REFERENCES}

1. Antony AC. Megaloblastic Anemias. In: Hoffman R, Benz (Jr) EJ, Silberstein LE, Heslop HE, Weitz JI, Anastasi J, eds. Hematology: Basic Principles and Practice Edition 6. Philadelphia: Elsevier Saunders; 2013:473-504.

2. Crider KS, Bailey LB, Berry RJ. Folic acid food fortification-its history, effect, concerns, and future directions. Nutrients 2011;3:370-84.

3. Bestwick JP, Huttly WJ, Morris JK, Wald NJ. Prevention of neural tube defects: a cross-sectional study of the uptake of folic acid supplementation in nearly half a million women. PLoS One 2014;9:e89354.

4. Torheim LE, Ferguson EL, Penrose K, Arimond M. Women in resource-poor settings are at risk of inadequate intakes of multiple micronutrients. J Nutr 2010;140:2051S-8S.

5. Bailey LB, Stover PJ, McNulty H, et al. Biomarkers of Nutrition for Development-Folate Review. J Nutr 2015;145:1636S-80S.

6. Antony AC. Megaloblastic Anemias. In: Goldman L, Schafer AI, eds. Goldman-Cecil Medicine, (Cecil's Textbook of Medicine) 25th Edition. New York: Elsevier Saunders; 2015:1104-14.

7. Antony AC. Vegetarianism and vitamin B-12 (cobalamin) deficiency. Am J Clin Nutr 2003;78:3-

6.

8. Chanarin I. The Megaloblastic Anemias. Oxford: Blackwell Scientific Publications; 1979.

9. Stabler SP, Allen RH, Savage DG, Lindenbaum J. Clinical spectrum and diagnosis of cobalamin deficiency. Blood 1990;76:871-81.

10. Lindenbaum J, Healton EB, Savage DG, et al. Neuropsychiatric disorders caused by cobalamin deficiency in the absence of anemia or macrocytosis. N Engl J Med 1988;318:1720-8.

11. Healton EB, Savage DG, Brust JC, Garrett TJ, Lindenbaum J. Neurologic aspects of cobalamin deficiency. Medicine (Baltimore) 1991;70:229-45.

12. Smith AD, Smith SM, de Jager CA, et al. Homocysteine-lowering by B vitamins slows the rate of accelerated brain atrophy in mild cognitive impairment: a randomized controlled trial. PLoS One 2010;5:e12244.

13. Antony AC. Megaloblastic Anemias. In: Hoffman R, Benz (Jr.) EJ, Shattil SJ, Furie B, Cohen HJ, eds. Hematology: Basic Principles and Practice. First ed. New York: Churchill-Livingstone; 1991:392422.

14. Herbert V, Zalusky R. Interrelations of vitamin B12 and folic acid metabolism: folic acid clearance studies. J Clin Invest 1962;41:1263-76.

15. Waters AH, Mollin DL. Observations on the metabolism of folic acid in pernicious anaemia. $\mathrm{Br} \mathbf{J}$ Haematol 1963;9:319-27.

16. Cooper BA, Lowenstein L. Relative folate deficiency of erythrocytes in pernicious anemia and its correction with cyanocobalamin. Blood 1964;24:502-21.

17. Saraya AK, Choudhry VP, Ghai OP. Interrelationships of vitamin B 12 , folic acid, and iron in anemia of infancy and childhood: effect of vitamin B 12 and iron therapy on folate metabolism. Am J Clin Nutr 1973;26:640-6.

18. Saraya AK, Singla PN, Ramachandran K, Ghai OP. Nutritional macrocytic anemia of infancy and childhood. Am J Clin Nutr 1970;23:1378-84.

19. Nixon PF, Bertino JR. Impaired utilization of serum folate in pernicious anemia. A study with radiolabeled 5-methyltetrahydrofolate. J Clin Invest 1972;51:1431-9.

20. Stabler SP, Marcell PD, Podell ER, Allen RH, Savage DG, Lindenbaum J. Elevation of total homocysteine in the serum of patients with cobalamin or folate deficiency detected by capillary gas chromatography-mass spectrometry. J Clin Invest 1988;81:466-74.

21. Shane B, Stokstad EL. Vitamin B12-folate interrelationships. Annu Rev Nutr 1985;5:115-41.

22. Hoffbrand AV, Newcombe FA, Mollin DL. Method of assay of red cell folate activity and the value of the assay as a test for folate deficiency. J Clin Pathol 1966;19:17-28.

23. Savage D, Lindenbaum J. Anemia in alcoholics. Medicine (Baltimore) 1986;65:322-38. 
24. Bain BJ, Wickramasinghe SN, Broom GN, Litwinczuk RA, Sims J. Assessment of the value of a competitive protein binding radioassay of folic acid in the detection of folic acid deficiency. J Clin Pathol 1984;37:888-94.

25. Chanarin I, Rothman D, Ward A, Perry J. Folate status and requirement in pregnancy. Br Med J 1968;2:390-4.

26. Gilois CR, Dunbar DR. Measurement of low serum and red cell folate levels: a comparison of analytical methods. Med Lab Sci 1987;44:33-40.

27. Brown RD, Uhr E, Watman R, Hughes W, Arnold B. The impact of the QAP survey on the performance of red cell folate assays. Pathology 1991;23:365.

28. Jaffe JP, Schilling RF. Erythrocyte folate levels: a clinical study. Am J Hematol 1991;36:116-21.

29. Farrell CJ, Kirsch SH, Herrmann M. Red cell or serum folate: what to do in clinical practice? Clin Chem Lab Med 2013;51:555-69.

30. Pfeiffer CM, Caudill SP, Gunter EW, Osterloh J, Sampson EJ. Biochemical indicators of B vitamin status in the US population after folic acid fortification: results from the National Health and Nutrition Examination Survey 1999-2000. Am J Clin Nutr 2005;82:442-50.

31. Green R. Indicators for assessing folate and vitamin B12 status and for monitoring the efficacy of intervention strategies. Food Nutr Bull 2008;29:S52-63; discussion S4-6.

32. Yetley EA, Pfeiffer CM, Phinney $\mathrm{KW}$, et al. Biomarkers of folate status in NHANES: a roundtable summary. Am J Clin Nutr 2011;94:303S-12S.

33. Stabler SP. Clinical practice. Vitamin B12 deficiency. N Engl J Med 2013;368:149-60.

34. Allen RH, Stabler SP, Savage DG, Lindenbaum J. Diagnosis of cobalamin deficiency I: usefulness of serum methylmalonic acid and total homocysteine concentrations. Am J Hematol 1990;34:90-8.

35. Duggan C, Srinivasan K, Thomas T, et al. Vitamin B-12 supplementation during pregnancy and early lactation increases maternal, breast milk, and infant measures of vitamin B-12 status. J Nutr 2014;144:758-64.

36. Refsum H, Yajnik CS, Gadkari M, et al. Hyperhomocysteinemia and elevated methylmalonic acid indicate a high prevalence of cobalamin deficiency in Asian Indians. Am J Clin Nutr 2001;74:23341.

37. Antony AC. Prevalence of cobalamin (vitamin B-12) and folate deficiency in India--audi alteram partem. Am J Clin Nutr 2001;74:157-9.

38. Yajnik CS, Lubree HG, Thuse NV, et al. Oral vitamin B12 supplementation reduces plasma total homocysteine concentration in women in India. Asia Pac J Clin Nutr 2007;16:103-9.

39. Herbert V. The 1986 Herman award lecture. Nutrition science as a continually unfolding story: the folate and vitamin B-12 paradigm. Am J Clin Nutr 1987;46:387-402.

40. Yajnik CS, Deshmukh US. Fetal programming: maternal nutrition and role of one-carbon metabolism. Rev Endocr Metab Disord 2012;13:121-7.

41. Fleming AF, Leveille GA. Folate activity and ascorbic acid in serum of anemic pregnant Nigerian women. Am J Clin Nutr 1969;22:642-5.

42. Lowenstein L, Brunton L, Hsieh YS. Nutritional anemia and megaloblastosis in pregnancy. Can Med Assoc J 1966;94:636-45.

43. Yusufji D, Mathan VI, Baker SJ. Iron, folate, and vitamin B 12 nutrition in pregnancy: a study of 1000 women from southern India. Bull World Health Organ 1973;48:15-22.

44. Stabler SP, Allen RH. Vitamin B12 deficiency as a worldwide problem. Annu Rev Nutr 2004;24:299-326.

45. Chakravarty I, Sinha RK. Prevalence of micronutrient deficiency based on results obtained from the national pilot program on control of micronutrient malnutrition. Nutr Rev 2002;60:S53-8.

46. Pathak P, Kapil U, Yajnik CS, Kapoor SK, Dwivedi SN, Singh R. Iron, folate, and vitamin B12 stores among pregnant women in a rural area of Haryana State, India. Food Nutr Bull 2007;28:435-8.

47. Pathak P, Kapil U, Kapoor SK, et al. Prevalence of multiple micronutrient deficiencies amongst pregnant women in a rural area of Haryana. Indian J Pediatr 2004;71:1007-14. 
48. Misra A, Vikram NK, Pandey RM, et al. Hyperhomocysteinemia, and low intakes of folic acid and vitamin B12 in urban North India. Eur J Nutr 2002;41:68-77.

49. World-Health-Organization. Trends in Maternal Mortality: 1990 to 2010. WHO, UNICEF, UNFPA and The World Bank estimates (2012). http://www.unfpa.org/webdav/site/global/shared/documents/publications/2012/Trends_in_mater nal_mortality_A4-1.pdf (accessed May 1,2013).

50. Waters AH, Mollin DL. Studies on the folic acid activity of human serum. J Clin Pathol 1961;14:335-44.

51. Tamez PA, Liu H, Fernandez-Pol S, Haldar K, Wickrema A. Stage-specific susceptibility of human erythroblasts to Plasmodium falciparum malaria infection. Blood 2009;114:3652-5.

52. Wasantwisut E, Neufeld L. Use of nutritional biomarkers in program evaluation in the context of developing countries. J Nutr 2012;142:186S-90S.

53. Dalal BI, Brigden ML. Factitious biochemical measurements resulting from hematologic conditions. Am J Clin Pathol 2009;131:195-204.

54. Kurtzhals JA, Rodrigues O, Addae M, Commey JO, Nkrumah FK, Hviid L. Reversible suppression of bone marrow response to erythropoietin in Plasmodium falciparum malaria. Br J Haematol 1997;97:169-74.

55. Verhoef H, West CE, Kraaijenhagen R, et al. Malarial anemia leads to adequately increased erythropoiesis in asymptomatic Kenyan children. Blood 2002;100:3489-94.

56. Antony AC, Utley C, Van Horne KC, Kolhouse JF. Isolation and characterization of a folate receptor from human placenta. J Biol Chem 1981;256:9684-92.

57. Antony AC, Kincade RS, Verma RS, Krishnan SR. Identification of high affinity folate binding proteins in human erythrocyte membranes. J Clin Invest 1987;80:711-23.

58. Antony AC, Bruno E, Briddell RA, Brandt JE, Verma RS, Hoffman R. Effect of perturbation of specific folate receptors during in vitro erythropoiesis. J Clin Invest 1987;80:1618-23.

59. Trager W. The enhanced folic and folinic acid contents of erythrocytes infected with malaria parasites. Exp Parasitol 1959;8:265-73.

60. Reid VE, Friedkin M. Plasmodium berghei: folic acid levels in mouse erythrocytes. Exp Parasitol 1973;33:424-8.

61. Antony AC. Megaloblastic Anemias. In: Hoffman R, Benz (Jr.) EJ, Shattil SJ, et al., eds. Hematology Basic Principles and Practice, Third Edition. Philadelphia: Churchill Livingstone; 2000:4601 .

62. Zhao R, Matherly LH, Goldman ID. Membrane transporters and folate homeostasis: intestinal absorption and transport into systemic compartments and tissues. Expert Rev Mol Med 2009;11:e4.

63. Herrmann W, Schorr H, Obeid R, Geisel J. Vitamin B-12 status, particularly holotranscobalamin II and methylmalonic acid concentrations, and hyperhomocysteinemia in vegetarians. Am J Clin Nutr 2003;78:131-6.

64. Taleb NN. Fooled by Randomness. Chapter 11: Kafka in a Courtroom (pages 154-156) http://www.dixiederivatives.com/Taleb/FooledByRandomness.pdf: Random House; 2001.

65. Taleb NN. The Black Swan: The Impact of the Highly Improbable. The New York Times, 22 April 2007 2007;Sect. http://www.nytimes.com/2007/04/22/books/chapters/0422-1st-tale.html.

66. Abdalla S, Weatherall DJ, Wickramasinghe SN, Hughes M. The anaemia of P. falciparum malaria. Br J Haematol 1980;46:171-83.

67. Abdalla SH. Hematopoiesis in human malaria. Blood Cells 1990;16:401-16; discussion 17-9.

68. Kandji ST, Verchot L, Mackensen J. Climate Variability and Climate Change in the Sahel Region: Impacts and Adaptation Strategies in the Agricultural Sector. A Joint Publication of The World Agroforestry Centre (ICRAF) and United Nations Environment Programme (UNEP). pp. 48 (2006). http://www.unep.org/Themes/Freshwater/Documents/pdf/ClimateChangeSahelCombine.pdf (accessed July 28, 2013).

69. Abdalla SH. Iron and folate status in Gambian children with malaria. Ann Trop Paediatr 1990;10:265-72. 
70. Abdalla SH, Wickramasinghe SN, Weatherall DJ. The deoxyuridine suppression test in severe anaemia following Plasmodium falciparum malaria. Trans R Soc Trop Med Hyg 1984;78:60-3.

71. Wickramasinghe SN, Abdalla SH. Blood and bone marrow changes in malaria. Baillieres Best Pract Res Clin Haematol 2000;13:277-99.

72. Weatherall DJ, Miller LH, Baruch DI, et al. Malaria and the red cell. Hematology Am Soc Hematol Educ Program 2002:35-57.

73. Lamikanra AA, Brown D, Potocnik A, Casals-Pascual C, Langhorne J, Roberts DJ. Malarial anemia: of mice and men. Blood 2007;110:18-28.

74. Roberts D. Anemia in malaria. In: SL Schrier JD, JS Timauer, and EL Baron (Eds), ed. Retrieved from UpToDate: http://wwwuptodatecom/contents/anemia-inmalaria? source $=$ machineLearning $\&$ search $=$ anemia + in + malaria\&selectedTitle $=1 \sim 150 \&$ sectionR ank=1\&anchor=H5 - H5 (Topic 7112 Version 180; Updated October 20, 2015; Accessed on April 29, 2016): Wolters Kluwer Health; 2016.

75. Calis JC, Phiri KS, Faragher EB, et al. Severe anemia in Malawian children. N Engl J Med 2008;358:888-99.

76. Antony AC. Severe anemia in Malawian children. N Engl J Med 2008;358:2291; author reply

77. Food-and-Agriculture-Organization http://www.fao.org/ag/agn/nutrition/mwi en.stm. 2010 . (Accessed July 28, 2013),

78. Huddle JM, Gibson RS, Cullinan TR. The impact of malarial infection and diet on the anaemia status of rural pregnant Malawian women. Eur J Clin Nutr 1999;53:792-801.

79. van den Broek NR, Letsky EA. Etiology of anemia in pregnancy in south Malawi. Am J Clin Nutr 2000;72:247S-56S.

80. National-Statistical-Office. Malawi Demographic and Health Survey 2000 (http://www.dhsprogram.com/pubs/pdf/FR123/FR123.pdf) (accessed on May 1, 2016). 2001.

81. Dagnelie PC, van Staveren WA. Macrobiotic nutrition and child health: results of a populationbased, mixed-longitudinal cohort study in The Netherlands. Am J Clin Nutr 1994;59:1187S-96S.

82. Louwman MW, van Dusseldorp M, van de Vijver FJ, et al. Signs of impaired cognitive function in adolescents with marginal cobalamin status. Am J Clin Nutr 2000;72:762-9.

83. van Dusseldorp M, Schneede J, Refsum H, et al. Risk of persistent cobalamin deficiency in adolescents fed a macrobiotic diet in early life. Am J Clin Nutr 1999;69:664-71.

84. Sneed SM, Zane C, Thomas MR. The effects of ascorbic acid, vitamin B6, vitamin B12, and folic acid supplementation on the breast milk and maternal nutritional status of low socioeconomic lactating women. Am J Clin Nutr 1981;34:1338-46.

85. Black AK, Allen LH, Pelto GH, de Mata MP, Chavez A. Iron, vitamin B-12 and folate status in Mexico: associated factors in men and women and during pregnancy and lactation. J Nutr 1994;124:117988.

86. Siekmann JH, Allen LH, Bwibo NO, Demment MW, Murphy SP, Neumann CG. Kenyan school children have multiple micronutrient deficiencies, but increased plasma vitamin B-12 is the only detectable micronutrient response to meat or milk supplementation. J Nutr 2003;133:3972S-80S.

87. Kahneman D. Thinking, fast and slow. New York: Farrar, Straus and Giroux. (499 pages); 2011.

88. Kipling R. The Jungle Book: The Century Co. New York. (303 pages), pp. 74; 1920.

89. van Hensbroek MB, Jonker F, Bates I. Severe acquired anaemia in Africa: new concepts. Br J Haematol 2011;154:690-5.

90. Ouma P, Parise ME, Hamel MJ, et al. A randomized controlled trial of folate supplementation when treating malaria in pregnancy with sulfadoxine-pyrimethamine. PLoS Clin Trials 2006;1:e28.

91. Chango A, Abdennebi-Najar L. Folate metabolism pathway and Plasmodium falciparum malaria infection in pregnancy. Nutr Rev 2011;69:34-40.

92. Mashako L, Preziosi P, Nsibu C, et al. Iron and folate status in Zairian mothers and their newborns. Ann Nutr Metab 1991;35:309-14.

93. Mulenga $\mathrm{M}$, Malunga $\mathrm{P}$, Bennett $\mathrm{S}$, et al. Folic acid treatment of Zambian children with moderate to severe malaria anemia. Am J Trop Med Hyg 2006;74:986-90. 
94. Mahalle N, Kulkarni MV, Garg MK, Naik SS. Vitamin B12 deficiency and hyperhomocysteinemia as correlates of cardiovascular risk factors in Indian subjects with coronary artery disease. J Cardiol 2013;61:289-94.

95. Yajnik CS, Deshpande SS, Jackson AA, et al. Vitamin B12 and folate concentrations during pregnancy and insulin resistance in the offspring: the Pune Maternal Nutrition Study. Diabetologia 2008;51:29-38.

96. Bharathi AV, Kurpad AV, Thomas T, Yusuf S, Saraswathi G, Vaz M. Development of food frequency questionnaires and a nutrient database for the Prospective Urban and Rural Epidemiological (PURE) pilot study in South India: methodological issues. Asia Pac J Clin Nutr 2008;17:178-85.

97. Murphy SP, Weinberg-Andersson, S. W., Neumann, C. G., Mulligan, K. \& Calloway, D. H. Development of research data bases: an example using foods consumed in rural Kenya. J. Food Comp. Anal. 4: 2-17. 1991.

98. Murphy SP, Gewa C, Grillenberger M, Neumann CG. Adapting an international food composition table for use in rural Kenya. Journal of Food Composition and Analysis 2004;17:523-30.

99. Gibson RS. Principles of Nutritional Assessment. Oxford: Oxford University Press, UK; 2005.

100. Neumann CG, Bwibo NO, Murphy SP, et al. Animal source foods improve dietary quality, micronutrient status, growth and cognitive function in Kenyan school children: background, study design and baseline findings. J Nutr 2003;133:3941S-9S.

101. National-Nutrition-Monitoring-Bureau. Prevalence of Micronutrient Deficiencies. NNMB Technical Report No. 22. National Institute of Nutrition Indian Council of Medical Research. Hyderabad, India2003:1-66 (http://nnmbindia.org/downloads.html) (Accessed on June 19, 2014).

102. Rao B. Nutrient requirement and safe dietary intake for Indians. Bulletin of the Nutrition Foundation of India 2010;31:1-5.

103. McLean E, Cogswell M, Egli I, Wojdyla D, de Benoist B. Worldwide prevalence of anaemia, WHO Vitamin and Mineral Nutrition Information System, 1993-2005. Public Health Nutr 2009;12:44454.

104. Toteja GS, Singh P, Dhillon BS, et al. Prevalence of anemia among pregnant women and adolescent girls in 16 districts of India. Food Nutr Bull 2006;27:311-5.

105. Kalaivani K. Prevalence \& consequences of anaemia in pregnancy. Indian J Med Res 2009;130:627-33.

106. DeMaeyer E, Adiels-Tegman M. The prevalence of anaemia in the world. World Health Stat Q 1985;38:302-16.

107. Human-Rights-Watch. No tally of the anguish: Accountability in maternal health care in India. http://www.hrw .org/reports/2009/10/08/no-tally-anguish-0 (accessed May 1, 2013). 2009.

108. Horton R, Lo S. Nutrition: a quintessential sustainable development goal. Lancet 2013;382:371-2. 109. Maternal-and-Child-Nutrition-Study-Group. Maternal and child nutrition: building momentum for impact. Lancet 2013;382:372-5.

110. Sengupta S. As Indian Growth Soars, Child Hunger Persists. The New York Times, published on March 12, 2009

http://wwwnytimescom/2009/03/13/world/asia/13malnutritionhtml? $\mathrm{r}=0$ (accessed on June 30, 2014) 2009.

111. Whaley SE, Sigman M, Neumann C, et al. The impact of dietary intervention on the cognitive development of Kenyan school children. J Nutr 2003;133:3965S-71S.

112. Raven JC. The Coloured Progressive Matrices Test. London, UK: Lewis; 1965.

113. Czeizel AE, Dudas I. Prevention of the first occurrence of neural-tube defects by periconceptional vitamin supplementation. N Engl J Med 1992;327:1832-5.

114. Berry RJ, Li Z, Erickson JD, et al. Prevention of neural-tube defects with folic acid in China. China-U.S. Collaborative Project for Neural Tube Defect Prevention. N Engl J Med 1999;341:1485-90.

115. Czeizel AE. Periconceptional folic acid and multivitamin supplementation for the prevention of neural tube defects and other congenital abnormalities. Birth Defects Res A Clin Mol Teratol 2009;85:260-8. 
116. Piedrahita JA, Oetama B, Bennett GD, et al. Mice lacking the folic acid-binding protein Folbp1 are defective in early embryonic development. Nat Genet 1999;23:228-32.

117. Antony AC, Hansen DK. Hypothesis: folate-responsive neural tube defects and neurocristopathies. Teratology 2000;62:42-50.

118. Hansen DK, Grafton TF, Streck RD. Modulation of folate receptor expression in vitro by antisense oligonucleotides produces neural tube defects in mouse embryos. Teratology 1999;59:385 (Abstr).

119. Hansen DK, Streck RD, Antony AC. Antisense modulation of the coding or regulatory sequence of the folate receptor (folate binding protein-1) in mouse embryos leads to neural tube defects. Birth Defects Res A Clin Mol Teratol 2003;67:475-87.

120. Evans AS. Causation and disease: a chronological journey. The Thomas Parran Lecture. Am J Epidemiol 1978;108:249-58.

121. Cherian A, Seena S, Bullock RK, Antony AC. Incidence of neural tube defects in the leastdeveloped area of India: a population-based study. Lancet 2005;366:930-1.

122. Kulkarni ML, Mathew MA, Reddy V. The range of neural tube defects in southern India. Arch Dis Child 1989;64:201-4.

123. Mahadevan B, Bhat BV. Neural tube defects in Pondicherry. Indian J Pediatr 2005;72:557-9.

124. Verma IC. High frequency of neural-tube defects in North India. Lancet 1978;1:879-80.

125. Bhide P, Sagoo GS, Moorthie S, Burton H, Kar A. Systematic review of birth prevalence of neural tube defects in India. Birth Defects Res A Clin Mol Teratol 2013;97:437-43.

126. Karmarkar SJ. Folate-Preventable Spina Bifida (SB) - Indian Scenario. In: Technical Consultation on Prevention of Folic Acid Deficiency and Strategies to Alleviate the Consequences; August 04, 2006: Office of the Micronutrient Initiative (MI), C-43, Niti Bagh, New Delhi-110049. http://www.docstoc.com/docs/85878650/Technical-Consultation-on-Prevention-of-Folic-Acid-

Deficiency-and (accessed May 1, 2013); 2006.

127. Li K, Wahlqvist ML, Li D. Nutrition, One-Carbon Metabolism and Neural Tube Defects: A Review. Nutrients 2016:(Nov 23;8(11). pii: E741. (http://www.mdpi.com/2072-6643/8/11/741)).

128. Molloy AM, Kirke PN, Brody LC, Scott JM, Mills JL. Effects of folate and vitamin B12 deficiencies during pregnancy on fetal, infant, and child development. Food Nutr Bull 2008;29:S101-11; discussion S12-5.

129. Schlotz W, Jones A, Phillips DI, Gale CR, Robinson SM, Godfrey KM. Lower maternal folate status in early pregnancy is associated with childhood hyperactivity and peer problems in offspring. $\mathrm{J}$ Child Psychol Psychiatry 2010;51:594-602.

130. Steenweg-de Graaff J, Roza SJ, Steegers EA, et al. Maternal folate status in early pregnancy and child emotional and behavioral problems: the Generation R Study. Am J Clin Nutr 2012;95:1413-21.

131. Suren P, Roth C, Bresnahan M, et al. Association between maternal use of folic acid supplements and risk of autism spectrum disorders in children. JAMA 2013;309:570-7.

132. Strand TA, Taneja S, Ueland PM, et al. Cobalamin and folate status predicts mental development scores in North Indian children 12-18 mo of age. Am J Clin Nutr 2013;97:310-7.

133. Xiao S, Hansen DK, Horsley ET, et al. Maternal folate deficiency results in selective upregulation of folate receptors and heterogeneous nuclear ribonucleoprotein-E1 associated with multiple subtle aberrations in fetal tissues. Birth Defects Res A Clin Mol Teratol 2005;73:6-28.

134. Ferguson SA, Berry KJ, Hansen DK, Wall KS, White G, Antony AC. Behavioral effects of prenatal folate deficiency in mice. Birth Defects Res A Clin Mol Teratol 2005;73:249-52.

135. Tang YS, Khan RA, Zhang Y, et al. Incrimination of heterogeneous nuclear ribonucleoprotein E1 (hnRNP-E1) as a candidate sensor of physiological folate deficiency. J Biol Chem 2011;286:39100-15.

136. Titaley CR, Dibley MJ, Roberts CL, Agho K. Combined iron/folic acid supplements and malaria prophylaxis reduce neonatal mortality in 19 sub-Saharan African countries. Am J Clin Nutr 2010;92:23543.

137. Okebe JU, Yahav D, Shbita R, Paul M. Oral iron supplements for children in malaria-endemic areas. Cochrane Database Syst Rev 2011:CD006589. 
138. Salcedo-Sora JE, Ochong E, Beveridge S, et al. The molecular basis of folate salvage in Plasmodium falciparum: characterization of two folate transporters. J Biol Chem 2011;286:44659-68.

139. van Eijk AM, Ouma PO, Williamson J, et al. Plasma folate level and high-dose folate supplementation predict sulfadoxine-pyrimethamine treatment failure in pregnant women in Western kenya who have uncomplicated malaria. J Infect Dis 2008;198:1550-3.

140. Metz J. Folic acid metabolism and malaria. Food Nutr Bull 2007;28:S540-9.

141. van Hensbroek MB, Morris-Jones S, Meisner S, et al. Iron, but not folic acid, combined with effective antimalarial therapy promotes haematological recovery in African children after acute falciparum malaria. Trans R Soc Trop Med Hyg 1995;89:672-6.

142. Carter JY, Loolpapit MP, Lema OE, Tome JL, Nagelkerke NJ, Watkins WM. Reduction of the efficacy of antifolate antimalarial therapy by folic acid supplementation. Am J Trop Med Hyg 2005;73:166-70.

143. Center-for-Disease-Control-and-Prevention. CDC Treatment Guidelines: Treatment of Malaria (Guidelines for $\quad$ Clinicians), July $2013, \quad$ Pages $\quad 1-8$. http://www.cdc.gov/malaria/resources/pdf/clinicalguidance.pdf (accessed August 1, 2013).

144. Center-for-Disease-Control-and-Prevention. Intermittent Preventive Treatment of Malaria for Pregnant Women (IPTp) http://www.cdc.gov/malaria/malaria_worldwide/reduction/iptp.html (accessed July 28, 2013).

145. Vanderjagt DJ, Ujah IA, Patel A, et al. Subclinical vitamin B12 deficiency in pregnant women attending an antenatal clinic in Nigeria. J Obstet Gynaecol 2009;29:288-95.

146. Czeizel AE, Bartfai Z, Banhidy F. Primary prevention of neural-tube defects and some other congenital abnormalities by folic acid and multivitamins: history, missed opportunity and tasks. Ther Adv Drug Saf 2011;2:173-88.

147. Oppenheimer SJ, Cashin P. Serum and red cell folate levels associated with malarial parasitaemia. Trans R Soc Trop Med Hyg 1986;80:169-71. 


\section{Table 1. Serum folates are Misleadingly Elevated in Vitamin-B ${ }_{12}$ Deficiency and/or Malaria Which Are Both Common in Resource-Limited Settings ${ }^{*}$ (From Ref. ${ }^{6}$ )}

\begin{tabular}{|c|c|c|c|}
\hline & Serum folates & Erythrocyte folates & Serum Vitamin-B $B_{12}$ \\
\hline Pure Folate deficiency & Low & Low & Normal/Low* \\
\hline Pure Vitamin- $B_{12}$ deficiency ${ }^{\Psi}$ & Normal/High $*^{\Psi}$ & $\operatorname{Low}^{* \Psi}$ & Low \\
\hline Folate plus Vitamin- $\mathrm{B}_{12}$ deficiency & Normal* & Low & Low \\
\hline Pure Malaria & Normal*/High $* \xi$ & $\mathrm{High}^{* \Phi \zeta}$ & Normal \\
\hline Malaria plus Folate deficiency & Normal* & Normal*/High*/Low & Normal \\
\hline Malaria plus Vitamin- $\mathrm{B}_{12}$ deficiency & Normal*/High* $* \xi$ & Normal*/High* $* \zeta$ & Low \\
\hline Malaria plus Folate plus Vitamin- $\mathrm{B}_{12}$ deficiency & Normal*/High* $* \xi$ & Low/Normal ${ }^{\zeta} \Omega$ & Low \\
\hline
\end{tabular}

* The asterisk indicates misleading values in the clinical settings shown on the left.

${ }^{\S}$ Both vitamin- $B_{12}$ deficiency and clinical malaria and other hemolytic states can complicate the diagnosis of folate deficiency using tests for serum- or erythrocyte- folate concentration. ${ }^{147}$

${ }^{\Psi}$ Vitamin- $B_{12}$ deficiency is accompanied by inability to utilize folates for one-carbon metabolism so folates leak out of erythroid precursors into serum.

${ }^{\xi}$ Release of the 30-fold excess folate from infected erythroid precursors, reticulocytes, and mature erythrocytes during hemolysis raises serum folate levels. (An as-yet-unknown quantity of folate is released into serum when folate-rich hepatocytes are destroyed during the exo-erythrocytic hepatic phase of malaria).

${ }^{\Phi}$ Hemolysis induces a compensatory reticulocytosis; these reticulocytes are richer in folate than mature erythrocytes. ${ }^{14,56,58}$

${ }^{\zeta}$ Plasmodium falciparum can also synthesize folates in erythrocyte cultures in vitro ${ }^{59}$ and raises erythrocyte folates in animal models with high levels of parasitemia. ${ }^{60}$

${ }^{\Omega}$ Reticulocytopenia in severe Plasmodium falciparum malaria, due to either combined vitamin- $\mathrm{B}_{12}$ deficiency plus folate deficiency, which can trigger a reticulocytopenic (megaloblastic) crisis], or cytokine-induced inhibition of hematopoiesis, will negate an expected rise in erythrocyte folates. 


\section{Table 2.}

\section{Interpretation of test results on serum methylmalonic acid and total homocysteine} (adapted from Ref. ${ }^{1}$ )

\begin{tabular}{|c|c|c|}
\hline Methylmalonic Acid* & Total Homocysteine $^{\S \xi}$ & Diagnosis \\
\hline Increased & Increased & $\begin{array}{l}\text { Vitamin-B }{ }_{12} \text { deficiency confirmed; } \\
\text { folate deficiency still possible } \\
\text { (i.e., combined vitamin- } \mathrm{B}_{12} \underline{\text { plus }} \\
\text { folate deficiency is possible) }^{\xi}\end{array}$ \\
\hline Normal & Increased & Folate deficiency is likely \\
\hline Normal & Normal & $\begin{array}{l}\text { Vitamin- } B_{12} \text { and folate deficiency } \\
\text { is excluded }\end{array}$ \\
\hline
\end{tabular}

\footnotetext{
* Methylmalonic acid (normal values $=70-270 \mathrm{nM}$ )

${ }^{\S}$ Homocysteine (normal values $\left.=5-14 \mu \mathrm{M}\right)$

$\xi$ In patients with combined folate plus vitamin- $\mathrm{B}_{12}$ deficiency, the serum homocysteine will not fall completely into the normal range unless both folate and vitamin- $\mathrm{B}_{12}$ are replaced.$^{34}$ Less commonly, with pyridoxine deficiency, specific replacement with pyridoxine will be required before the serum homocysteine falls into the normal range.
} 